\title{
worldview
}

A JOURNAL OF ETHICS AND FOREION AFFAIRs

\section{THE ISSUES WE FACE}

January, 1958, is not a happy time for the world: it is a time of troubles. Triumphs of Soviet science are accompanied by growing recklessness in Soviet policy. Beneath the pieties and platitudes of official pronouncements, we see deepening disharmonies within the Western alliance. Despite giddy changes in the world situation, no new policies, no new ideas are born in the chancellories of the West. Rather, faced with new threats, new dangers, new opportunities, even, our statesmen retreat to the false comfort of banalities. Yeats, some might think, described our situation: "The best lack all conviction, while the worst are filled with passionate intensity."

Many of this nation's friends are greatly worried. Some of them fear that the United States, lulled into illusion by its past achievements, has failed to realize the terrible implications of the new Soviet science. One of the warmest and most perceptive of them, Professor Denis W. Brogan, declares: "For the first time in my thirty year's study of the American way of life, I am not convinced that it, at the moment, has what it takes to win this contest. I am convinced that it will prove not to have it if there is not a very fundamental stocktaking that will involve the abandoning of some very comforting illusions and, indeed, of some totally justified beliefs that were true only yesterday."

The illusions? "The naive one that all technical progress is the work of Americans;" and "the respect given to the business man ... as a representative figure ... who organizes the great human and physical resources of the United States to produce 'the American way of life."

Other of America's friends are troubled by what they believe is the single-minded sterility of this country's approach to the Soviet Unionan approach which is based on military stereotypes and which does not realize that the ultimate threat from world Communism may be the political threat. An influential British journal recently published a cartoon which showed Mr. John Foster Dulles confronted with a series of political challenges from Premier Bulganin. At each challenge the Secretary of State took deep thought.
And then, in each case, he came up with his answer: "More armsl"

-

The dreary catalogue of our difficulties could be continued; dangers are everywhere. And the need for continuing examinations of the dangers, for continuing exchanges of ideas on ways to meet them, must be felt by all of us.

One of the most vexing-and most immediateproblems we face is how to respond adequately to the dangers without, in the process, undermining or destroying our own moral and intellectual tradition of civilized life. Can this tradition be saved, and the free nations of the world along with it, in an age of unparalleled, total, thermonuclear threat? And if this tradition cannot be saved, what is the fight all about?

It is to deal with such questions as these that Worldview is published. This journal, which sucseeds the World Alliance Neiws Letter, and is sponsored by The Church Peace Union, is concerned with the broad area of ethtes and foreign affairs. And it is concerned with this area as a baffling and heart-breaking problem, not an accomplishment. At all times, among all nations, a tension between ethics and foreign policy seems inevitable. In the world of 1958, when thermonuclear weapons have brought a new dimension of destruction into history, the tension is infinitely heightened. Worldview will seek to explore the implications of this fact.

As a publication of The Church Peace Union, Worldview is edited from the viewpoint of the West's perennial tradition, which is deeply, essentially rooted in the values of the Judeo-Christian, classical humanist view of man and society. This journal will not "preach," but it will insist-sometimes explicitly, more often implicitly-that this tradition is relevant to, even normative for, the survival of any world worth saving. Protestants, Catholics, Jews, and others who hold that man is both in history and beyond history, and that this duality of the human vocation has practical consequences for political affairs, will write for the magazine. We hope they will be read. 